\title{
The Effect of sieved Coal Bottom Ash as a Sand Substitute on the Properties of Concrete with Percentage Variation in Cement
}

\author{
M. P. Kadam ${ }^{1, *}$, Y. D. Patil ${ }^{2}$ \\ ${ }^{1}$ Department Civil Engineering, NDMVPS's KBT College of Engineering, Nashik, India \\ ${ }^{2}$ Department of Applied Mechanics, SVNIT, Surat, India \\ *Corresponding author: kadammadhav@yahoo.co.in
}

Received August 30, 2014; Revised September 07, 2014; Accepted September 11, 2014

\begin{abstract}
This paper presents the results of an experimental investigation on the effect of sieved coal bottom ash as a substitute for natural sand on the properties of concrete, when an extra $5 \%, 10 \%, 15 \%, 20 \%, 25 \%$ and $30 \%$ weight of cement was added. First, M-35 grade concrete was casted and tested; using a fixed percentage of $70 \%$ sieved coal bottom ash and 30\% natural sand. The water cement ratio was maintained at 0.45 . Then various tests including compressive strength, split tensile strength, flexural strength, density and water permeability were performed on the sieved coal bottom ash concrete. The results were compared with the control concrete and the percentage variations in strength were studied at 7, 28, 56 and 112 days. The results indicate a considerable increase in strength when $20 \%$ extra cement was added with the weight of cement.
\end{abstract}

Keywords: sieved bottom ash, compressive strength, split tensile strength, flexural strength, water permeability

Cite This Article: M. P. Kadam, and Y. D. Patil, "The Effect of sieved Coal Bottom Ash as a Sand Substitute on the Properties of Concrete with Percentage Variation in Cement." American Journal of Civil Engineering and Architecture, vol. 2, no. 5 (2014): 160-166. doi: 10.12691/ajcea-2-5-2.

\section{Introduction}

Concrete is extensively used as construction material in domestic, recreational and other spheres across the world. Cement, aggregate and water are the main constituent materials forming concrete. Concrete includes the following: air nearly 6\%; Portland cement $11 \%$; coarse aggregate $41 \%$; fine aggregate $26 \%$ and water $16 \%$ by volume. Natural resources are continuously being depleted worldwide, while simultaneously the wastes thus generated from the industry are substantially increasing. Sustainable development for construction involves the use of nonconventional and innovative materials as well as the recycling of waste materials to compensate for the lack of natural resources and the discovery of alternative methods of environment conservation. Aggregates are regarded as one of the main constituents of concrete as they constitute more than 65\% of the concrete matrix. Many countries face a dearth of natural aggregates suitable for construction, while some other countries experience an increase in the consumption of the aggregates due to the growing demand by the construction industry.

In a review of the recent research, the possibility of exploiting industrial byproducts as well as other waste materials to produce normal concrete and high strength concrete when used as a partial or whole replacement of aggregate became evident [11]. It also confirmed that the concrete produced by incorporating industrial wastes possessed superior properties when compared with conventional concrete in terms of strength, performance and durability [12]. In this paper experimental investigations were conducted to study the effect of the use of sieved coal bottom ash as a substitute for natural sand on the properties of concrete and with the addition of an extra $5 \%$, $10 \%, 15 \%, 20 \%, 25 \%, 30 \%$ of cement by weight of the cement used in the control mix.

Andrade L.B. and Rocha et al., [2] reported that because the bottom ash porosity was high, the w/c ratio of the concrete could not be accepted as accurate, whereas Chai Jaturapitakkul and Raungrut Cheerarot [3] reported that the bottom ash had a potential high enough to function as a good pozzolanic material. Rafat Siddique [15] conducted a detailed investigation on the mechanical properties of various concrete mixtures in which fine aggregates were partially replaced with class F fly ash by weight. Trakool Aramraks [17] reported that bottom ash required approximately 25 to $50 \%$ more water content than normal concrete did to achieve suitable workability. Bottom ash concrete was also found to exhibit greater permeability than did normal concrete. Aggarwal P. and Aggarwal Y. et al., [1] reported that the workability of concrete decreased with the increase in bottom ash due to the increased water demand. H. K. Kim and H. K. Lee [5] performed a detailed experimental investigation to evaluate the effect of fine and coarse bottom ash on the flow characteristics and density of the concrete mixture. They found that both the fine and coarse bottom ash aggregates exerted greater influence on the flexural 
strength than on the compressive strength. Ratchayut Kasemchaisir and Somnuk Tangtermsirikul [16] reported that the durability, chloride ion permeability, carbonation depth and shrinkage in drying using $10 \%$ bottom ash were higher than those of the control concrete. The pozzolanic activity of the bottom ash with lime was very low until 14 days of hydration. Pozzolanic activity commenced at 28 days and the calcium hydroxide consumption assumed great significance at 90 days. Mohd Syahrul Hisyam bin Mohd Sani, Fadhluhartini bt Muftah [13] et al., showed that the sieve analysis conducted on the washed bottom ash from the Electric Power Station, TNB Perak, was used for mortar more suitably than for concreting sand. Washed bottom ash replacement $30 \%$ was found to be the optimum amount to achieve favorable strength and a good strength development pattern over the increment ages. O. E. Manz [14] accomplished a detailed investigation on the world's production and utilization of coal ash and presented a country-by-country survey of the use of coal ash in concrete; however, Ratchayut Kasemchaisir and Somnuk Tangtermsirikul [16] arrived at experimental results which revealed that the slump flow and L-box passing ability of the concrete with bottom ash was reduced. Y. Bai and P. A. M. Basheer [19] reported that the workability of the concrete improved with the increase in fine bottom ash. Y. Bai and F. Darcy et al., [18] studied the strength and drying shrinkage of concretes having the natural sand replaced by furnace bottom ash at $0 \%, 30 \%$, $50 \%, 70 \%$ and $100 \%$ by mass, with respect to their fixed water to cement ratios (W/C) and fixed slump ranges. The results showed that at the fixed water-cement ratios the compressive strength and drying shrinkage decreased with the increased content of the furnace bottom ash. However, at fixed workability, the compressive strength was comparable with that of the control concrete.

\section{Materials and Method}

\subsection{Cement}

Ultra Tech 53 grade Ordinary Portland cement was used for this study. This is the most widely used cement in the Indian construction industry.

\subsection{Coarse and Fine Aggregates}

In this study, $10 \mathrm{~mm}$ and $20 \mathrm{~mm}$ sized coarse aggregates taken from Mhasrul-Nashik, Maharashtra were used with natural sand from the river bed conforming to the grading Zone I of Table 4 of IS:383 [5] procured from the Tapi river, Nandurbar, Maharashtra.

\subsection{Coal Bottom Ash}

Coal bottom ash was obtained from Eklahare Thermal Power Plant in Nashik, Maharashtra, India.

\subsection{Plasticizers}

Emceplast BV Plasticizer was used in accordance with manufacturer's instructions to improve the workability of the fresh concrete mix.

\subsection{Water}

Potable water was used for casting and currying of the concrete blocks.

\section{Physical and Chemical Properties Material}

\subsection{Fineness Modulus of Fine and Coarse Aggregates}

To determine the Fineness Modulus of the $20 \mathrm{~mm}$ coarse aggregates, sand and sieved bottom ash, a detailed sieve analysis was performed. The Fineness Modulus of the coarse aggregates $(20 \mathrm{~mm})$, sand and coal bottom ash were 7.64, 3.47 and 3.12, respectively, as shown in Table 1. It was ensured that both aggregates had a grain size distribution within $4.75-20 \mathrm{~mm}$ by sieving, in order to avoid any effect due to aggregate size. According to the IS:383-1970 [7] specifications any grading falling outside the limits of a particular grading zone of sieves other than the 600-micron IS Sieve by a total not exceeding 5\% would be regarded as being included within that grading zone. This tolerance will not include any percentage beyond the 600-micron IS Sieve or a percentage crossing any other sieve size on the coarse limit of Grading Zone I or the finer limit of Grading Zone IV. Sand used in this work ranged from grading Zone I and the sieved bottom ash used in this work fell under Zone II. In Figure 1 the particle size distributions for 30\% natural sand and 70\% sieved bottom ash which lies in Zone I are shown.

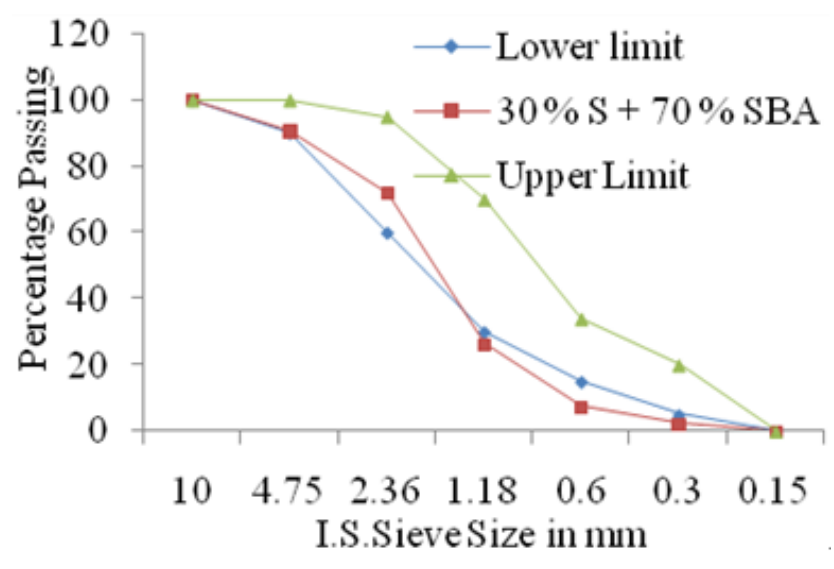

Figure 1. Gradation of 30\% sand and 70\% sieved bottom ash in zone I

\subsection{Specific Gravity of Fine and Coarse Aggregates}

To determine the specific gravity of the $20 \mathrm{~mm}$ aggregate a density bucket was used and the specific gravity of the $20 \mathrm{~mm}$ aggregates was found to be 2.67 as seen in Table 1 . The specific gravity of the sand and sieved bottom ash was determined using a pycnometer [6] and found to be 2.62 and 1.925, respectively. It was observed that the specific gravity of the sieved bottom ash was less when compared with that of the sand.

\subsection{Water Absorption}

The water absorption of the $20 \mathrm{~mm}$ coarse aggregates, sand and sieved coal bottom ash determined by the conventional method were found to be $0.601,1.01$ and 
21.09, respectively. The water absorption of the sieved coal bottom ash was found to be very high when compared with the natural sand affecting the workability of the concrete. The water absorption of the coarse aggregates, sand and sieved bottom ash are shown in Table 1. The water absorption of the sieved coal bottom ash was high because of the high porosity and low specific gravity. The Fineness Modulus and specific gravity are also shown in Table 1 for the coarse aggregates, natural sand and sieved bottom ash.

Table 1. Physical Properties of Coarse and Fine Aggregates with Sieved Coal Bottom Ash

\begin{tabular}{|c|c|c|c|c|c|c|c|c|}
\hline \multicolumn{2}{|c|}{ Fineness Modulus } & \multicolumn{3}{c|}{ Specific Gravity } & \multicolumn{3}{c|}{ Water Absorption } \\
\hline C.A.. & Sand & S.C.B.A. & C.A. & Sand & S.B.A. & C.A. & Sand & S.B.A \\
\hline 7.64 & 3.47 & 3.12 & 2.67 & 2.62 & 1.925 & 0.601 & 1.01 & 21.09 \\
\hline
\end{tabular}

\subsection{Chemical Composition of the Sieved Bottom Ash}

The chemical composition of the sieved bottom ash was analyzed by the gravimetric method according to IS: $1727-1967$ on the $600 \mathrm{~g}$ sample and the results are tabulated in Table 2. It was found that the sieved coal bottom ash used in this work was in the combined percentage of Silica + Alumina + Iron Oxide 91.25\% and the percentage Silica is $60.63 \%$, which confirms the minimum requirement as per the IS :3812-1981 mentioned above. The loss in ignition was 6.04 , slightly higher than the IS requirement.

Table 2. Chemical Analysis of Sieved Bottom Ash

\begin{tabular}{|c|c|c|}
\hline Chemical composition & $\begin{array}{l}\text { Sieved Bottom Ash } \\
\text { Weight percent }\end{array}$ & $\begin{array}{c}\text { IS: 3812- } 1981 \\
\text { Requirement }\end{array}$ \\
\hline $\begin{array}{c}\mathrm{SiO}_{2}+\mathrm{Al}_{2} \mathrm{O} 3+\mathrm{Fe}_{2} \mathrm{O}_{3} \\
\text { (Silica }+ \text { Alumina }+ \text { Iron Oxide) }\end{array}$ & 91.25 & $70 \mathrm{~min}$ \\
\hline $\mathrm{SiO}_{2}$ (Silica) & 60.63 & $35.0 \mathrm{~min}$ \\
\hline $\mathrm{CaO}$ (Alumina) & 1.09 & Not Specified \\
\hline MgO (Magnesia) & 0.40 & $5.0 \max$ \\
\hline $\mathrm{SO}_{3}$ & 0.58 & $3.0 \max$ \\
\hline $\mathrm{Na}_{2} \mathrm{O}$ & 0.45 & $1.5 \max$ \\
\hline Total Chlorides & 0.058 & $0.05 \max$ \\
\hline Loss in Ignition at $1000^{\circ} \mathrm{C}$ & 6.04 & 5.0 \\
\hline
\end{tabular}

\subsection{Laboratory Testing Program}

The mix proportion and mix ratio selected for this study are as shown in Table 3 . Concrete mixtures containing different proportions of the sieved coal bottom ash ranging from $0 \%$ (for the control mix) to 10 to $100 \%$ replacement for sand were considered. The M-35 grade mix design was selected for the w/c ratio of 0.45 . In this study, the slump was maintained at $100 \pm 10 \mathrm{~mm}$. For this work we used a total of 231 cubic, 132 cylindrical and 132 beam specimens, which were casted and tested for compressive strength, split tensile strength, flexural strength and water permeability. Table 4 shows the material utilized possessing different proportions of sieved coal bottom ash mixed with cement in $\mathrm{kg} / \mathrm{m}^{3}$. The mix design selected was for a w/c ratio of 0.45 for the control concrete in which 6 cubes were casted and tested for 7 and 28 days. The compressive strength at 7 and 28 days was found to be $28.21 \mathrm{~N} / \mathrm{mm}^{2}$ and $42.93 \mathrm{~N} / \mathrm{mm}^{2}$, respectively. For the control concrete 21 cubical, 12 cylindrical and 12 beam specimens were casted and tested for 7, 28, 56 and 112 days during the process.

\subsubsection{Preparation of the Test Specimens}

To mix the concrete we used half a bag of mixer. First, coarse aggregates $20 \mathrm{~mm}$ and $10 \mathrm{~mm}$ in size were placed in the mixer along with $60 \%$ of the $20 \mathrm{~mm}$ aggregates and $40 \%$ of the $10 \mathrm{~mm}$ aggregates. Then sand and cement were mixed together in the dry state. Finally, water was added and mixed until a homogeneous mixture was obtained. Each batch was mixed for approximately 3 to 5 minutes and the mixture was placed in a metallic tray. The slump was checked immediately before the concrete was placed in a different mold. In this work, drinking water was used throughout the curing process.

\subsubsection{Cube Shaped Specimen}

Cubes $150 \mathrm{~mm} \times 150 \mathrm{~mm} \times 150 \mathrm{~mm}$ in size were used. The cube molds were cleaned thoroughly and properly oiled along their faces. The mold was then filled with concrete in three layers and compacted using a $600 \mathrm{~mm}$ tamping rod, $25 \mathrm{~mm}^{2}$ in cross-sectional area. Further, the molds were placed on the vibrating table for 60 seconds to achieve proper compaction and subsequently maintained on a plane and level surface in the laboratory for 24 hours. The cubes were demolded and set aside for curing.

\begin{tabular}{|c|c|c|c|c|}
\multicolumn{7}{c}{ Table 3. Mix Proportions $\left(\mathbf{K g} / \mathbf{m}^{3}\right)$} & and Mix Ratio \\
\hline Cement & $\begin{array}{c}\text { Fine } \\
\text { aggregates } \\
\text { (sand) }\end{array}$ & $\begin{array}{c}\text { Coarse } \\
\text { aggregates } \\
(20 \mathrm{~mm})\end{array}$ & $\begin{array}{c}\text { Coarse } \\
\text { aggregates } \\
(10 \mathrm{~mm})\end{array}$ & Water \\
\hline 438 & 678.47 & 658.20 & 438.8 & 197 \\
\hline 1 & 1.55 & 1.50 & 1.0 & 0.45 \\
\hline
\end{tabular}

\subsubsection{Cylindrical Shaped Specimen}

Cylindrical molds $150 \mathrm{~mm}$ in diameter and $300 \mathrm{~mm}$ in height were used. The inner surfaces of the mold were oiled for smooth cylinder removal. Concrete was poured throughout its length and compacted well using a tamping rod as well as a vibrating table. In total, 132 cylindrical specimens were casted and tested.

\subsubsection{Beam Shaped Specimen}

A beam mold $100 \mathrm{~mm} \times 100 \mathrm{~mm} \times 500 \mathrm{~mm}$ in size was used. The inner mold surfaces were oiled for easy removal of the beam from the mold. Concrete was poured throughout its length and compacted well with a tamping rod as well as a vibrating table.

\subsubsection{Curing}

After all the cubes, cylindrical and beam specimens were cast they were placed in a curing tank for the curing process. Drinking water was used throughout. During curing the water was replaced with fresh water every seven days.

\section{Results and Discussion}

\subsection{Effect of the Sieved Coal Bottom Ash on Compressive Strength}


The compressive strength of the concrete mixes made with and without sieved coal bottom ash in the cubes 150 $\times 150 \times 150 \mathrm{~mm}$ in size were determined at 7, 28, 56 and 112 days of curing. The compressive strength test results are presented in Figure 2. Readings were taken for a maximum load at failure and the average compressive strength was calculated using the following equation.

$$
\begin{aligned}
& \text { Compressive strength }\left(\mathrm{N} / \mathrm{mm}^{2}\right) \\
= & \text { Ultimate load }(\mathrm{N}) / \text { Area of cross section }\left(\mathrm{mm}^{2}\right)
\end{aligned}
$$

\begin{tabular}{|c|c|c|c|c|c|c|c|}
\hline $\begin{array}{l}\text { Mix material and } \\
\text { Percentage } \\
\text { Replacement }\end{array}$ & Cement & $\begin{array}{c}\text { Sieved Coal } \\
\text { Bottom } \\
\text { Ash }\end{array}$ & Water & Sand & $\begin{array}{l}\text { C.A. } \\
10 \mathrm{~mm}\end{array}$ & $\begin{array}{c}\text { C.A. } \\
20 \mathrm{~mm}\end{array}$ & Admixture \\
\hline $\mathrm{CC}$ & 438 & - & 197 & 658.20 & 438.80 & 658.20 & - \\
\hline $70 \mathrm{SBA}+30 \mathrm{~S}$ & 438 & 460.74 & 197 & 197.46 & 438.80 & 658.20 & 0.986 \\
\hline $70 \mathrm{SBA}+30 \mathrm{~S}+5 \mathrm{C}$ & 459.9 & 460.74 & 197 & 197.46 & 438.80 & 658.20 & 0.986 \\
\hline $70 \mathrm{SBA}+30 \mathrm{~S}+10 \mathrm{C}$ & 481.8 & 460.74 & 197 & 197.46 & 438.80 & 658.20 & 1.035 \\
\hline $70 \mathrm{SBA}+30 \mathrm{~S}+15 \mathrm{C}$ & 503.7 & 460.74 & 197 & 197.46 & 438.80 & 658.20 & 1.035 \\
\hline $70 \mathrm{SBA}+30 \mathrm{~S}+20 \mathrm{C}$ & 525.6 & 460.74 & 197 & 197.46 & 438.80 & 658.20 & 1.133 \\
\hline $70 \mathrm{SBA}+30 \mathrm{~S}+25 \mathrm{C}$ & 547.50 & 460.74 & 197 & 197.46 & 438.80 & 658.20 & 1.133 \\
\hline $70 \mathrm{SBA}+30 \mathrm{~S}+30 \mathrm{C}$ & 569.4 & 460.74 & 197 & 197.46 & 438.80 & 658.20 & 1.232 \\
\hline
\end{tabular}

Table 4. Concrete Mixtures with Different Proportions of Sieved Bottom Ash in $\mathrm{kg} / \mathrm{m}^{3}$

Here, $70 \%$ of the sieved coal bottom ash was substituted with sand and the percentage of cement was increased with the weight of cement used in the mix design being added in various percentages from $5 \%$ to $30 \%$. The optimum percentage of the cement was obtained at $20 \%$ replacement of cement by weight of the cement used in the control mix. For the control concrete the compressive strength was found to be 27.71, 42.93, 50.56 and $51.70 \mathrm{~N} / \mathrm{mm}^{2}$ at 7, 28, 56 and 112 days, respectively. The compressive strengths at 7 days, 28 days, 56 days and 112 days for $70 \%$ SCBA + 30\% sand with $5 \%, 10 \%$, 15\%, $20 \%, 25 \%$ and $30 \%$ extra cement was added by weight of the cement used in the mix are presented in Figure 2. From the test results, the compressive strengths of the sieved coal bottom ash concrete mixes with 5\%, 10\%, $15 \%, 20 \%$, 25\% and 30\% extra cement was added by weight of the cement used in the control mix were observed to be higher than $70 \%$ SCBA $+30 \%$ sand at all ages. This increase in strength was due to the increase in the availability of the C-S-H gel, as shown in Figure 100. During the initial period the sieved bottom ash concrete was observed to gain strength at a slower rate, whereas after 28 days it was observed to have acquired strength at a faster rate due to the pozzolanic action of the bottom ash [15]. Segregation of the bottom ash particles at the top of the specimens was also observed during casting.

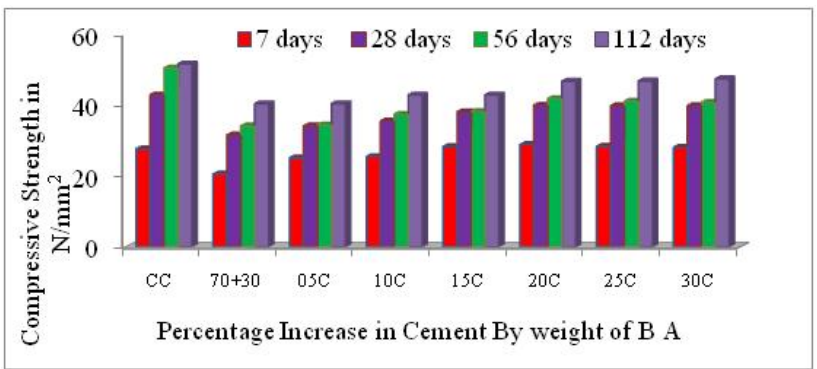

Figure 2. Compressive strength of the sieved bottom ash concrete with age

\subsection{Effect of the Sieved Coal Bottom Ash on Split Tensile Strength}

Specimens $150 \mathrm{~mm}$ in diameter and $300 \mathrm{~mm}$ in length were casted and tested under the calibrated digital CTM, of 300 ton capacity. The specimens were placed under CTM at the center with plywood at the top and bottom and a load was applied at a pace rate of $1.3 \mathrm{kN} /$ second and the ultimate loading was noted. The split tensile strength was calculated according to the IS: 5816-1970 [10] and IS: 516-1959 [9] code using the formula,

$$
\sigma_{b t}=2 P / \pi D L
$$

Where $\sigma_{b t}$ represents the split tensile strength in $\mathrm{N} / \mathrm{mm}^{2}$, $\mathrm{P}$ is maximum load at failure, $\mathrm{L}$ is the span and $\mathrm{D}$ is the diameter of the specimen. The split tensile strength for the control concrete was found to be 3.07, 3.92, 4 and 4.11 $\mathrm{N} / \mathrm{mm}^{2}$ for $7,28,56$ and 112 days, respectively. The split tensile strength at 7 days, 28, 56 and 112 days for the $70 \%$ SBA $+30 \%$ sand $+5 \%, 10 \%, 15 \%, 20 \%, 25 \%$ and $30 \%$ extra cement was added by weight of the cement in the control concrete mix as presented in Figure 3. It was observed from Figure 3 that the splitting tensile strength of concrete increased with the increase in the percentage of cement by weight of the cement used in the control mix. The maximum split tensile strength was observed when $20 \%$ extra cement was added by weight of the cement in the control mix, although for $25 \%$ and $30 \%$ extra cement the strength remained constant.

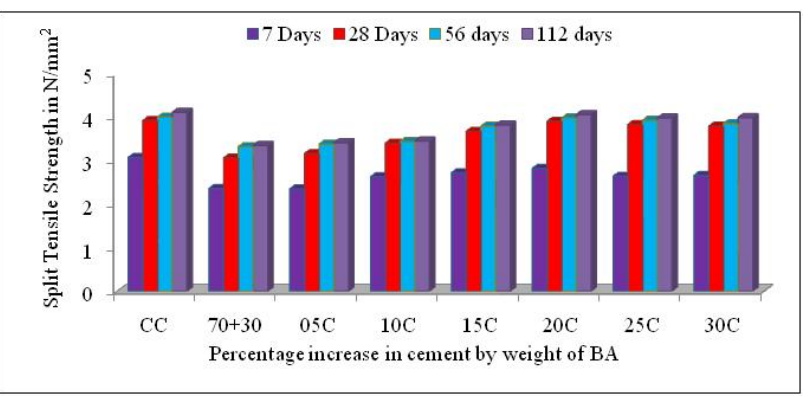

Figure 3. Split tensile strength of sieved bottom ash concrete with age

\subsection{Effect of the Sieved Coal Bottom Ash on Flexural Strength}


The beam specimens $100 \mathrm{~mm} \times 100 \mathrm{~mm} \times 500 \mathrm{~mm}$ in size were tested for a two point load at the middle third point under the UTM of 100 ton capacity. The flexural strength was calculated per IS 456 - 2000 [8] and IS 516 1959 [9] by using the relation

$$
\sigma_{\mathrm{b}}=\mathrm{PL} / \mathrm{bd}^{2}
$$

where $\sigma_{b}$ is the modulus of rupture in $\mathrm{N} / \mathrm{mm}^{2}, P$ is maximum load, $\mathrm{L}$ is span, $\mathrm{b}$ is width of the specimen and $\mathrm{d}$ is depth of the specimen.

The flexural strength increased as the percentage of cement increased by weight of the cement used in the control mix and maximum strength was found for $20 \%$ extra cement when compared with the control concrete. The sieved bottom ash concrete gains flexural strength with age although less than that of the control concrete. This is attributed to the poor interlocking between the aggregates, as the bottom ash particles are spherical in shape. Figure 4 shows variation in the flexural strength for different replacements with respect to the control concrete for 7 days, 28, 56 and 112 days.

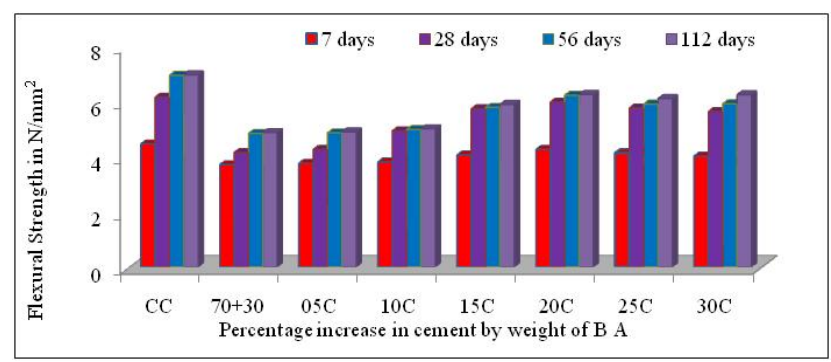

Figure 4. Flexural Strength of the sieved bottom ash concrete with age

\subsection{Effect of the Sieved Coal Bottom Ash on Density of the Concrete}

The densities of the hardened concrete specimens with $70 \%$ SCBA + 30\% sand + extra 5, 10, 15, 20, 25, 30\% cement by weight of the cement used in the control mix were determined. It was found that as the percentage of the cement increased, the density of the concrete also increased correspondingly when compared with the control concrete. In Figure 5 the density of the hardened concrete at 28 days is seen. The density of the hardened concrete was seen to linearly increase as the percentage of the cement increased. The density of the control concrete was $24.13 \mathrm{~kg} / \mathrm{m}^{3}$ for 28 days. The percentage density of the concrete for $5 \%$ to $30 \%$ cement increased by weight of the cement used in the control mix and was found to be 0.08 to $0.87 \%$.

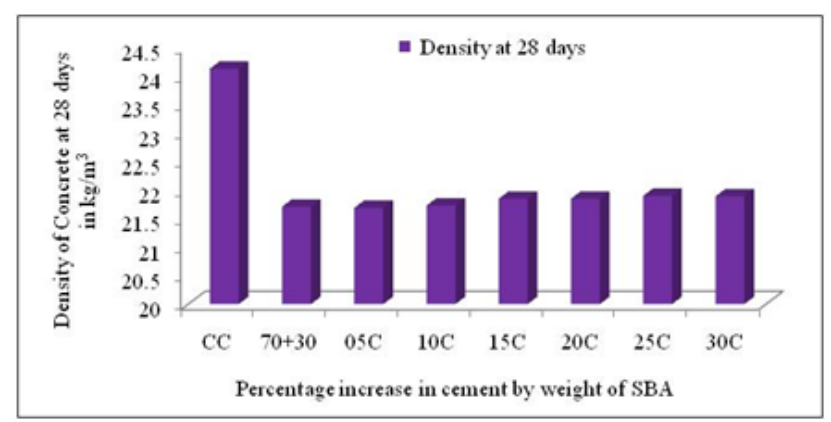

Figure 5. Density of the sieved bottom ash concrete at 28 days

\subsection{Effect of the Sieved Coal Bottom Ash on the Modulus of Elasticity at 28 Days}

The modulus of Elasticity of the cube specimen is calculated according to IS: 456-2000 [8] by the formula E $=5000 \sqrt{ } f_{c k}$ where $f_{c k}$ is the 28-day cube compressive strength. It was found that the Modulus of Elasticity decreased with a corresponding increase in the replacement of natural sand by the sieved coal bottom ash. The Modulus of Elasticity of the control concrete was 0.24 $\times 10^{5} \mathrm{~N} / \mathrm{mm}^{2}$. The Modulus of Elasticity for $70 \%$ SBA + $30 \%$ sand with $5,10,15,20,25$, and $30 \%$ extra cement by weight of the bottom ash was found to increase from 0.28 to $0.32 \times 10^{5} \mathrm{~N} / \mathrm{mm}^{2}$. Figure 6 shows the variation in the Modulus of Elasticity at 28 days.

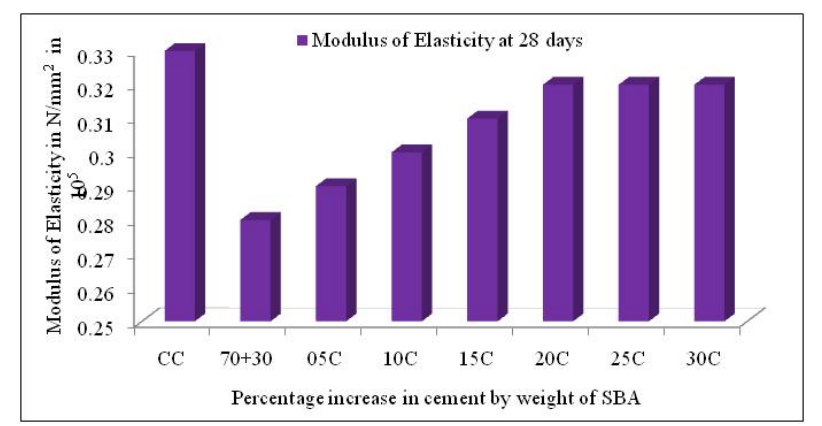

Figure 6. Modulus of Elasticity of the sieved bottom ash concrete at 28 days

\subsection{Effect of the Sieved Coal Bottom Ash on the Permeability of the Concrete at 28 Days}

Concrete cubes $150 \mathrm{~mm} \times 150 \mathrm{~mm} \times 150 \mathrm{~mm}$ in size were casted with and without the sieved coal bottom ash then cured for 28 days. The cubes were placed in the permeability test apparatus at a pressure of 5 bars for 72 hours. The cubes were removed from the set-up and placed one by one in the CTM using the splitting device provided with the equipment. The maximum water penetration levels were immediately noted. This test was conducted according to the German code DIN-1048 [4]. It was found that the permeability of up to $50 \%$ replacement decreased after which the permeability increased from $60 \%$ to $100 \%$ replacement. Figure 7 shows the variation in the permeability with respect to the control concrete.

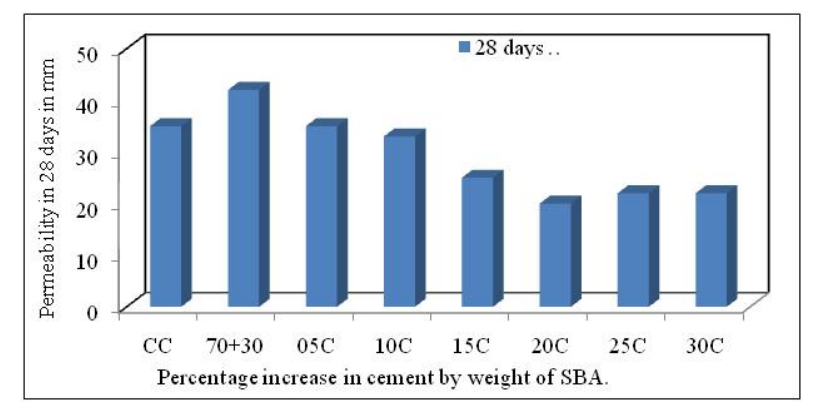

Figure 7. Permeability of the sieved bottom ash concrete at 28 days with variation in cement

\subsection{SEM Observations}

Figure 8 is the Scanning Electron Micrograph of the control concrete mix which reveals the presence of sand particles in a mixed state and as separate particles but 
prominently visible. The mix also shows a dense matrix with no pores or cracks. Gel formation is clearly visible around the sand particles in the micrograph. Figure 9 shows micrographs of the $70 \%$ sieved coal bottom ash and $30 \%$ sand with $10 \%$ extra cement added with the weight of cement required in the control mix. This micrograph shows the bottom ash particles with micropores ranging in size from 13.1 to $17.8 \mu \mathrm{m}$ having some microcracks. The gel formation is clearly visible, with the microcracks occurring around the bottom ash particle, causing the strength of the concrete to become reduced to less than that of the control concrete. It also indicates that C-S-H gel is not available in sufficient quantity to bind the sieved bottom ash particles and form the dense structure of concrete. Figure 100 and Figure 111 show the SEM of the $20 \%$ and $25 \%$ extra addition of cement when compared with the control concrete mix and shows dense concrete with no cracks or pores present in the concrete. The C-S-H gel is more finely spread than is the control concrete. The availability of more gel has resulted in the greater strength, stronger than even the control mix. Due to the C-S-H gel formation at its peak the mix becomes denser which causes the increase in strength.

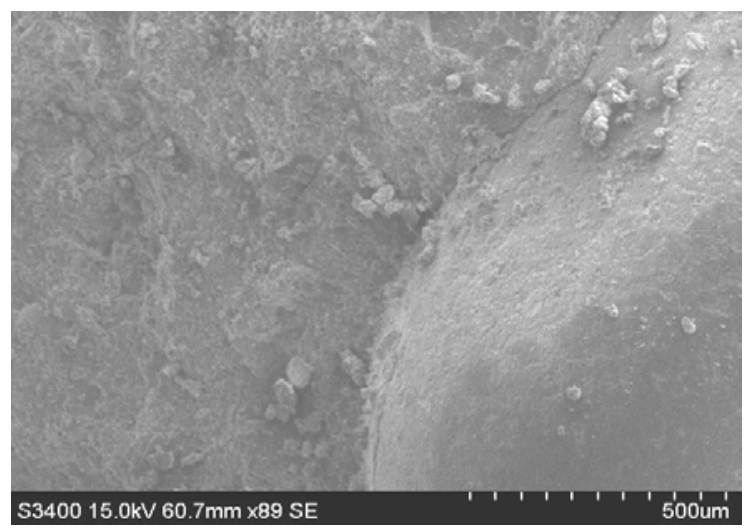

Figure 8. SEM micrograph of the control concrete at 112 days

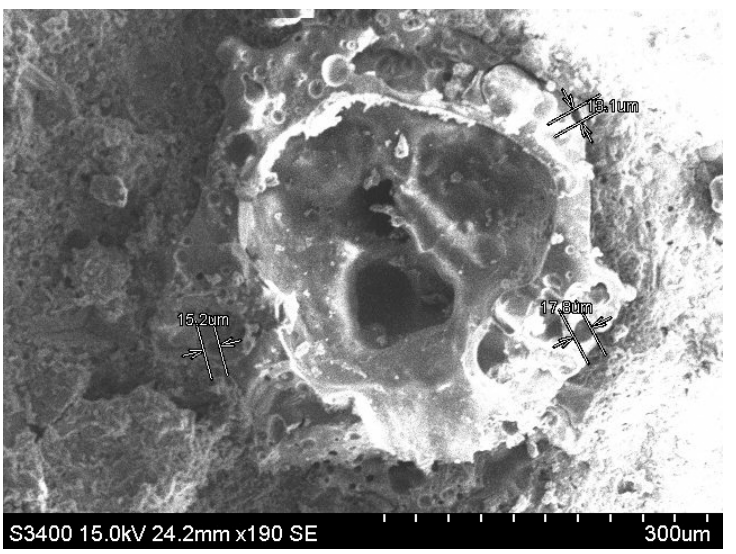

Figure 9. SEM micrograph of additionof $10 \%$ extra cement

\section{Conclusions}

1. The Maximum Compressive Strength and Modulus of Elasticity of the sieved bottom ash concrete increased correspondingly as the percentage of the cement increased by weight of the cement used in the control mix. Maximum strength was recorded at 20\% extra cement added by weight of the cement used in the control mix.

2. It was observed that when up to $20 \%$ of extra cement was added by weight of the cement used in the control mix, the strength increased, although after that it remained constant.

3. Compressive Strength and Flexural Strength increased due to fewer voids being formed in the concrete, with improved particle distribution.

4. Split tensile strength was observed to increase when up to $20 \%$ of extra cement was added to the control mix concrete, after which the strength remained constant.

5. The density of the sieved bottom ash concrete linearly increased as the percentage of the cement increased from $5 \%$ to $20 \%$ of that of normal concrete, after which it stayed constant.

6. Permeability was found to decrease when up to $20 \%$ of extra cement was used in the control mix, after which it remained constant.

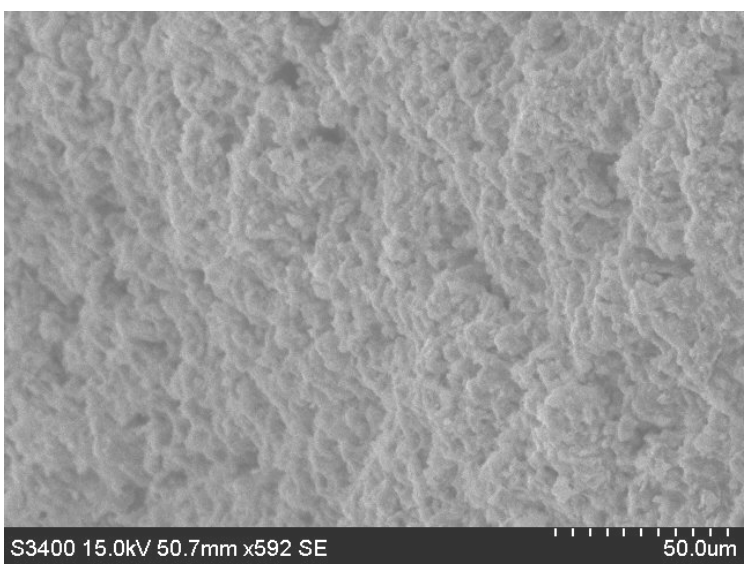

Figure 10. SEM micrograph of the addition of $20 \%$ extra cement

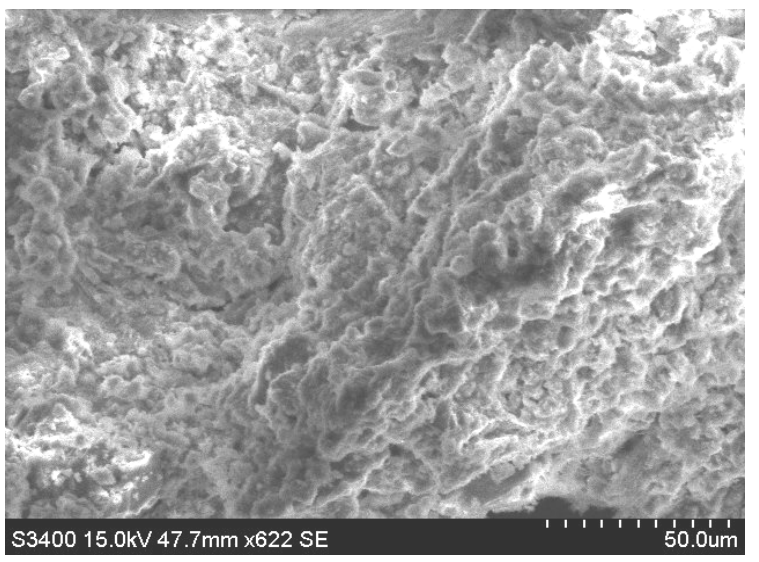

Figure 11. SEM of SEM micrograph of addition of 25\% extra cement

\section{References}

[1] Aggarwal P., Aggarwal Y, Gupt S.M., Effect of bottom ash as replacement of fine aggregates in concrete, Asian Journal of Civil Engineering (building and housing), 2007, Vol. 8, no. 1 Pages 4962.

[2] Andrade L.B., J.C. Rocha, M. Cheriaf, Influence of coal bottom ash as fine aggregate on fresh properties of concrete, Construction and Building Materials, 2009, Vol. 23, pp. 609-614.

[3] Chai Jaturapitakkul and Raungrut Cheerarot, Development of Bottom Ash as Pozzolanic material, Journal of Materials in Civil Engineering, 2003, Vol.15, pp. 48-53. 
[4] DIN 1048 (part-5): German Standard for determination of Permeability of Concrete.

[5] H.K. Kim, H.K. Lee, Use of power plant bottom ash as fine and coarse aggregates in high-strength concrete, Construction and Building Materials, 2011, Vol. 25, pp. 1115-1122.

[6] IS 2386-1963(part-III) Method for test for aggregates for Concrete

[7] IS 383-1970 - Specification for coarse and fine aggregates from the natural source for concrete.

[8] IS 456-2000 code of practice for plain and reinforced cement concrete for general construction work.

[9] IS 516 - 1959 Methods of test for strength of concrete.

[10] IS 5816 - 1970 Methods of test for splitting tensile strength of concrete cylinders.

[11] Malhotra V.M., and Mehta P.K., pozzolanic and cementitious materials, Gordon and Breach Publishers, Pennsylvania, 1996.

[12] Malhotra V.M. and Painter K.E., Early-age strength properties, and freezing and thawing resistance of concrete were incorporating high volume of ASTM Class F Fly ash, the International Journal of Cement Composites and Lightweight Concrete, 1995, Vol. 11 No. 1 pp. 38-46.

[13] Mohd Syahrul Hisyam bin Mohd Sani, Fadhluhartini bt Muftah, Zulkifli Muda, The Properties of Special Concrete Using Bottom Ash (WBA) as Partial Sand Replacement, International Journal of
Sustainable Construction Engineering \& Technology, 2010, Vol.2, pp. 65-76.O.

[14] O. E. Manz, Worldwide production of coal ash and utilization in concrete and other products, Elsevier Science Ltd. Fuel, 1997 Vol. 76, pp. 691-696.

[15] Rafat Siddique, Effect of fine aggregate replacement with Class $F$ fly ash on the abrasion resistance of concrete, Cement and Concrete Research, 2003, Vol. 33, pp. 1877-1881.

[16] Ratchayut Kasemchaisir and Somnuk Tangtermsirikul, Properties of Self-Compacting concrete in Corporating Bottom Ash as a Partial Replacement of Fine Aggregate, Science Asia, 2008, Vol. 34 pp. 87-95.

[17] Trakool ARAMRAKS Experimental Study of Concrete Mix with Bottom Ash as Fine Aggregate in Thailand, SEAMEOINNOTECH, 2006.

[18] Y. Bai, F. Darcy, P. A. M. Basheer, Strength and drying shrinkage properties of concrete containing furnace bottom ash as fine aggregate, Construction and Building Materials, 2005, Vol. 19, pp 691-697.

[19] Y. Bai and P. A. M. Basheer, Influence of furnace bottom ash on properties of concrete, Structures \& Buildings, 2003, Vol. 156, pp. 5-92. 